American Journal of Applied Sciences 6 (11): 1924-1931, 2009

ISSN 1546-9239

(C) 2009 Science Publications

\title{
A Bound Test Approach to Cointegration of Tourism Demand
}

\author{
Fateh Habibi and Khalid Abdul Rahim \\ Department of Hospitality and Recreation, Faculty of Economics and Management, \\ University Putra Malaysia, 43400, Serdang, Selangor, Malaysia
}

\begin{abstract}
Problem statement: Given the high contribution of tourism industry in the Malaysian economy, Malaysia has a vast view to increase its market share of the international tourist arrivals in the Asia Pacific region. Therefore, this study attempts to investigate the long run and short run demand for tourism from top ten markets (country). Approach: To accomplish this objective the ARDL bound test approach to cointegration was carried out for quarterly time series data from 1998:Q1 to 2007: Q3. A three-stage procedure followed to test the direction of causality. In the first stage the order of integration was tested using the Augmented Dickey-Fuller (ADF) and Phillips Perron (PP) unit root tests. The second stage involved testing for the existence of a long-run equilibrium relationship between arrivals, income, tourism price, tourism substitute price and travel cost. The third stage involved constructing standard Granger-type causality tests augmented with a lagged error-correction term where the series were cointegrated. Results: The result of ADF and PP unit root tests confirmed that all variables were stationary at first difference. In addition the results indicated that a long run relationship and between variables. Conclusion: The results indicated that tourists from these ten countries seem to be highly sensitive to the price and the alternative destinations are complementary to Malaysia. In addition the results showed that the outbreak of Severe Acute Respiratory Syndrome (SARS, 2003) had a negative affects significantly affected Malaysia's tourism demand.
\end{abstract}

Key words: Tourism demand, cointegration, ARDL

\section{INTRODUCTION}

Before its independence in 1957, the Malaysian economy was heavily dependent on primary commodities mainly tin, rubber, palm oil and petroleum products. Tourism industry affects positively on the economy besides an increase in foreign exchange earning and employment opportunities. The Malaysian government has serious attention to develop tourism industry after decrease in oil and the world economic recession in the middle of the 1980s. The Ministry of Culture, Arts and Tourism had established in 1987 and later upgraded it to the Ministry of Tourism in 2004. The government was also allocated amount of fund to tourism industry besides providing sufficient basic infrastructure. In 2006, tourism Malaysia received 30\% more funding for advertising and other promotions in preparation for Visit Malaysia Year in $2007^{[1]}$. The Malaysian government will spend RM1.8 billion under the Ninth Malaysian Plan (2006-2010), on upgrading tourist destinations and infrastructure, as well as on marketing promotions in major source markets ${ }^{[2]}$.
Figure 1 shows that in 1980, the total tourist arrivals to Malaysia were 2.3 million and increased to about 21 million in 2007 at an average annual rate of $10.1 \%$. Within the last 27 years total tourist arrivals to Malaysia had increased especially in visit Malaysia year's in 1990, 2000 and 2007 at a growth rate of 53.7, 28.9 and $19.5 \%$ respectively. Also tourist receipts had increased from RM 0.7 billion in 1980 to RM 46.1 billion in 2007 at an annual average rate of $18.4 \%{ }^{[3]}$. The Gulf War in 1991, the Asian financial crisis in 1997 and the outbreak of Severe Acute Respiratory Syndrome (SARS) in 2003 have negative affects on international tourist arrivals at an annual average rate of $-12.5,-13$ and $-20.4 \%$ respectively.

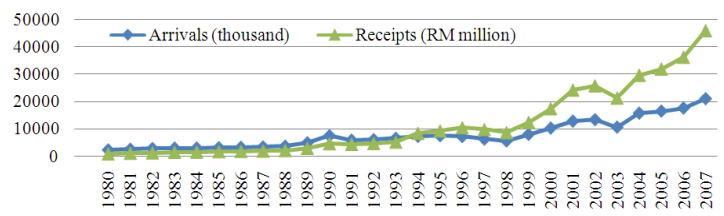

Fig. 1: International tourist arrivals and receipts in Malaysia, 1998-2007

Corresponding Author: Fateh Habibi, Department of Hospitality and Recreation, Faculty of Economics and Management, University Putra Malaysia, 43400, Serdang, Selangor, Malaysia

Tel: +60389467609 Fax: +60899486188 
Am. J. Applied Sci., 6 (11): 1924-1931, 2009

Table 1: Tourist arrivals by country of origin (2007)

\begin{tabular}{lcc}
\hline Country & Arrivals (thousand) & Share of total $(\%)$ \\
\hline Singapore & 10492692 & 59.96 \\
Indonesia & 1804535 & 10.31 \\
Thailand & 1625698 & 9.29 \\
Brunei & 1172154 & 6.70 \\
China & 689293 & 3.94 \\
India & 422453 & 2.41 \\
Japan & 367567 & 2.10 \\
Philippines & 327140 & 1.87 \\
Australia & 320363 & 1.83 \\
UK & 276213 & 1.58 \\
\hline Total & 17498108 & 100.00 \\
\hline
\end{tabular}

In terms of international tourist arrivals in 2006, Malaysia was ranked as the fourteen world's top tourist destinations with $2.2 \%$ of market share. Also in Asia and the Pacific region Malaysia was ranked as the second place with $10.5 \%$ of market share after china ${ }^{[4]}$. Table 1 shows the relative importance of each of the ten origins according to 2007 data on numbers of arrivals. In terms of constitution, it can be observed that international tourism is highly intensified in a few countries of origin. Singapore, Indonesia and Thailand more than $80 \%$ of international arrivals.

Hence, it is important to know the determinants of tourism demand from these markets in order to attract more tourists from these countries. Therefore serious attention should be given in studying the factors that affect international tourist arrivals to this country. The objective of this study is to identify and estimate the income, tourism price, tourism substitute price and travel cost of the tourism demand to Malaysia both in the short run and long run. The remainder of the study is organized as follows: Initially the literature review is described. The methodology and data used for investigate tourism demand is presented and follows the empirical results. Finally conclusion and policy implication are described.

Literature review: A large number of empirical studies on international tourism demand are found in the literature and are divided into two main categories. The first category includes of studies that estimate the determinants of international tourism demand using classical regressions. See for example ${ }^{[5-7]}$. The second category consists of studies that use modern time series and cointegration techniques. See, for example ${ }^{[8-11]}$. A number of the existing empirical studies have used tourist arrivals/departures ${ }^{[12-15]}$ and tourism receipts/expenditures as dependent variables ${ }^{[16,17]}$. The number of overnight stays and the average length of stay have also been studied, but much less frequently ${ }^{[18]}$.
Kulendran $^{[8]}$ analyzed the effects of marketing expenditure on tourism demand for Australasia using the ARDL model. They found that both the 'word-ofmouth effect' and visitor's satisfaction arrives to repeat visits also play an important role in promoting international tourist arrivals to Australia. Algieri ${ }^{[9]}$ used the VAR model to investigate the determinants of tourism receipts in Russia. The results show that the significant long-run cointegration relationship between Russian tourism receipts, real exchange rates, world GDP and air transport prices. Through an ARDL model, Narayan ${ }^{[10]}$ studied the tourism demand from Australia, New Zealand and the USA to Fiji for the period 1970-2000. He found that the tourism price is an important determinant of Fiji's tourism demand. A $1 \%$ increase in the cost of a holiday in Fiji relative to Bali leads to a decrease in tourists to Fiji of 5.1, 2.5 and $2.4 \%$ from the USA, Australia and New Zealand, respectively. Song et al. ${ }^{[1]}$ investigated tourism demand for Thailand and showed that the own price and cross price variables significant affects of decision making process of residents from Australia, Japan, Singapore and the UK. Their study also demonstrated that the terrorist attacks on the USA on 11 September 2001 and the war on Iraq and the SARS epidemic in 2003, significant affects on international tourism demand to Thailand. Ouerfelli ${ }^{[12]}$ implied that the relative prices and income are highly elastic for tourists to Tunisia. In addition the supply factor (hotel room) is significant in the destination choice decision especially for French and Italian tourists. Through an Error Correction (ECM) Model Dritsakis ${ }^{[13]}$ found that the long-run relationship among important economic variables determining German and United Kingdom tourism demand to Greece.

Through an Autoregressive Distributed Lag (ARDL) model Habibi et al. ${ }^{[14]}$ investigated Australian tourism demand to Malaysia for the period 1998: Q12007: Q3. The results implied that the price of tourism products and services and the outbreak of Severe Acute Respiratory Syndrome (SARS, 2003) significantly affected Malaysia's tourism demand. Mohd Salleh et al. ${ }^{[15]}$ found that income and tourism price have a significant effects on tourist arrivals to Malaysia from Singapore, Hong Kong, Japan and Australia. In addition they found that the Singapore is a complementary destination as shown by negative sign for Australia and Japan but a substitute destination (positive sign) for Hong Kong. Wade ${ }^{[16]}$ showed that the real exchange rate and all the age groups, with the exception of the under-18 age group are significant in explaining tourism expenditure in the case of Canada. Mervar $^{[17]}$ implied that the real exchange rate and 
Am. J. Applied Sci., 6 (11): 1924-1931, 2009

transportation costs are not statistically significant and the political instability negatively affects tourism demand for Croatian destinations. Hyndman ${ }^{[18]}$ studied the number of visitor nights based on the main purpose of travel: Holiday, visiting friends and relatives, business and other from first quarter of 1998 to second quarter of 2005 for Australia. They found that the negative relationship between the lag of the growth rate of DPI (the price index for domestic holiday travel and accommodation) and positive relationship between growth of Gross Domestic Product (GDP) and holiday travel. The results indicate that after the Bali bombings, Australians reverted to visiting friends and relatives more than before. They also investigated the impact of the 2000 Sydney Olympics and found a positive and statistically significant increase of business travel in the December Quarter of 2000.

\section{MATERIALS AND METHODS}

The model constructed is based on the classical economic theory which supposes that total tourist arrivals, as a measure of Malaysian tourism demand, are determined by the lagged tourist arrivals, level of income, tourism price, travel cost, tourist substitute piece and dummy variables. In investigating tourism demand to Malaysia from ten markets the following function is used:

$$
\begin{aligned}
& \operatorname{lnTA} A_{t}=\beta_{0}+\beta_{1} \operatorname{lnT} A_{t}+\beta_{2} \ln Y_{i, t}+\beta_{3} \operatorname{lnTP} P_{i, t}+\beta_{4} \operatorname{lnTC}_{i, t} \\
& +\beta_{5} \operatorname{lnTPS} \mathrm{j}_{\mathrm{j}, \mathrm{t}}+\beta_{6} \operatorname{lnTV} \mathrm{V}_{\mathrm{j}, \mathrm{t}}+\beta_{7} \mathrm{D} 03+\varepsilon_{\mathrm{it}}
\end{aligned}
$$

Where:

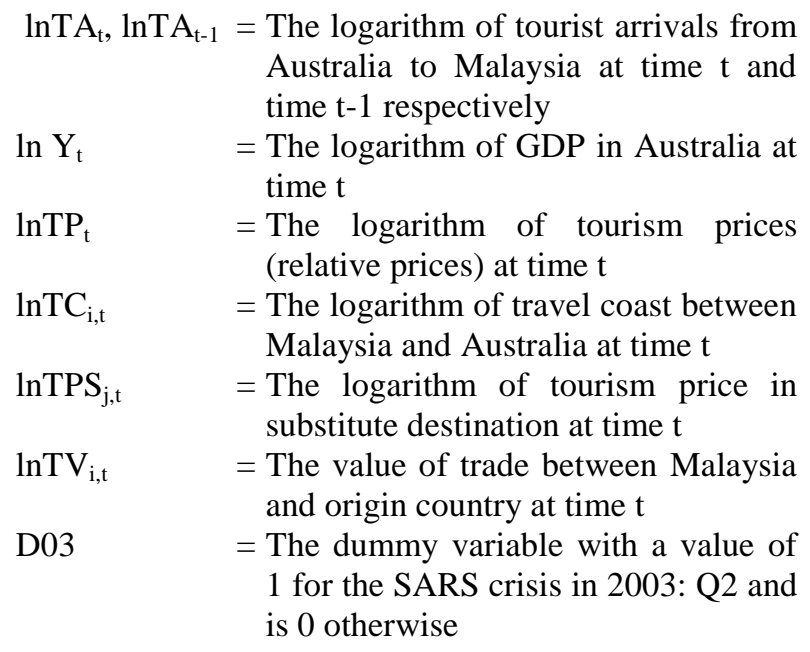

Dependent variable: The international tourism demand is often measured in terms of the number of tourist arrivals, tourist expenditure and number of tourist nights in the destination country ${ }^{[12]}$. In this study, the available data have not permitted the construction of a tourism receipts or number of tourist night's variables. An alternative way of measuring the volume of tourism is to use the number of tourists arriving at a Malaysia from Australia.

Independent variables: Lagged dependent variable: Once people have been on holiday to a special destination and liked it, they tend to come back to that destination. Moreover, information about the destination extends as people share their holiday experiences with friends and family, thus reducing the amount of uncertainty for potential visitors to that country. In fact this 'word of mouth' recommendation may well be involved a more important role in destination selection rather than commercial advertising. Therefore, the number of people choosing a given destination in any year depends on the numbers who chose it in the previous years ${ }^{[11]}$. Word of mouth is proxied by number of tourist arrivals in the past year. Income: This factor seems to be suitably measured by the disposable income level, however, because of the problem of data unavailability, the real Gross Domestic Product $(\mathrm{GDP})(2000=100)$ is used to measure the income variable in origin country.

Tourism price: The price of goods and services in the destination would usually account for a significant part of the total price. The consumer price indices were used as a proxy for the cost of tourism in Malaysia relative to the cost of living in Australia adjusted by the exchange rate ${ }^{[19-21]}$. We therefore expect a negative sign for this variable. The definition of the tourism price variable in this study is:

$\mathrm{TP}_{\mathrm{t}}=\left(\mathrm{CPI}_{\mathrm{m}, \mathrm{t}} / \mathrm{CPI}_{\mathrm{a}, \mathrm{t}}\right) \times\left(\mathrm{ER}_{\mathrm{m}, \mathrm{t}} / \mathrm{ER}_{\mathrm{a}, \mathrm{t}}\right)$

Where:

$\mathrm{TP}_{\mathrm{t}}=$ The tourism price in Malaysia relative to Australia at time $\mathrm{t}$

$\mathrm{CPI}_{\mathrm{m}, \mathrm{t}}=$ The consumer price index in Malaysia at time $\mathrm{t}$

$\mathrm{CPI}_{\mathrm{a}, \mathrm{t}}=$ The consumer price index in Australia at time $\mathrm{t}$

$\mathrm{ER}_{\mathrm{m}, \mathrm{t}}=$ The average rate of the Ringgit against the US dollar

$\mathrm{ER}_{\mathrm{a}, \mathrm{t}}=$ The average rate of the Australian dollar against the US dollar

Travel cost: Transportation costs have attracted much less attention in empirical studies, basically due to a lack of precise measures for effective transportation costs. Some of studies used airfares index between 
Am. J. Applied Sci., 6 (11): 1924-1931, 2009

origin and destination include ${ }^{[9,13]}$ and another studies used the price of crude oil for this variable ${ }^{[17]}$. In this study the price of crude oil is used as a proxy for this variable. We also expect a negative sign for the coefficient of this variable.

Substitute price: In the background of tourism, there are two possible substitution effects. The first substitution effect is substitution among competing destinations and the second is between international tourism and domestic tourism. Both geographic and cultural characteristics are considered when selecting the substitute destinations. In this study selects five most popular alternative destinations out of ten destinations in the Asia Pacific Region for tourists from the Australia as competitors for travel demand for Malaysia. These ten destinations from a competitor set in Asia in Dwyer ${ }^{[22]}$ where price competitiveness of travel and tourism is studied (China, Hong Kong, Indonesia, Japan, Macau, Philippines, Singapore, South Korea, Taiwan, Thailand). The substitute price index was calculated by weighing the consumer price index of each of the five substitute destinations (China, Indonesia, Singapore, Thailand and Hong Kong) according to its share of the international tourism arrivals and it is given as:

$\mathrm{TPE}=\sum_{\mathrm{j}=1}^{\mathrm{n}} \mathrm{w}_{\mathrm{j}} \mathrm{CPI}_{\mathrm{j}} / \mathrm{ER}_{\mathrm{j}}$

Where:

$\mathrm{CPI}_{\mathrm{j}}$ and $\mathrm{ER}_{\mathrm{j}}=$ Respectively, the consumer price index and the exchange rate of the currency of the rival country $j, j=1,2,3,4$ and 5

$\mathrm{w}_{\mathrm{j}} \quad=$ The share of international tourism arrivals for country $\mathrm{j}$ which is calculated from $w_{j}=\frac{T A j}{\sum_{j=1}^{5} T A j}$

$\mathrm{TA}_{\mathrm{j}}=$ Designates the tourist arrivals from country $\mathrm{j}, \sum_{\mathrm{j}=1}^{5} \mathrm{TAj}$ total arrivals
Trade value: Value of trade is hypothesized to affect the demand of travel to Malaysia and it was therefore contained in the model in order to help explain the tourism demand $d^{[11,23,24]}$. Value of trade is measure as the total value of import and export of goods and services between Malaysia and origin country. Table 2 shows the variables and data source ${ }^{[30,32]}$.

Before testing for cointegration between the variables we have to perform a test for a unit root using the ADF test based on the auxiliary regression with an intercept and trend (or without trend) following:

$\Delta \mathrm{Y}_{\mathrm{t}}=\beta_{1}+\beta_{2} \mathrm{t}+\delta \mathrm{Y}_{\mathrm{t}-1}+\sum_{\mathrm{i}=1}^{\mathrm{k}} \gamma_{\mathrm{i}} \Delta \mathrm{Y}_{\mathrm{t}-\mathrm{i}}+\varepsilon_{\mathrm{t}}$

Where:

$\varepsilon_{\mathrm{t}}=$ A pure white noise error term

$Y_{t}=$ The tourist arrivals variable (or each of them independent variables) to check whether it is stationary or not

$\Delta \mathrm{Y}_{\mathrm{t}}=\left(\mathrm{Y}_{\mathrm{t}}-\mathrm{Y}_{\mathrm{t}-1}\right)=$ the first difference operator

$\mathrm{I}=$ For lag length ${ }^{[25]}$

In conducting $\mathrm{ADF}$ test, lag length is very important, as it is sensitive to the test results. For selecting the lag length using an information criterion such as the Akaike Information Criterion (AIC) or the Schwarz Information Criterion (SBC).

Cointegration technique have developed and known as the 'Autoregressive Distributed Lag (ARDL)' Bound test by ${ }^{[26-28]}$. The ARDL bound test approach has several advantages over the Johansen's cointegration method following: First the ARDL model its ability to detect long run relationships and solve the small sample size problem. Second the ARDL approach can be applied irrespective of whether the underlying regressors are purely first order integrated, I(1), purely zero order integrated, $\mathrm{I}(0)$, or a mixture of both. Third advantage is in ARDL, one can include dummy variable in the cointegration test process.

Table 2: Variables and sources

\begin{tabular}{|c|c|c|c|}
\hline Variable & Proxy & Description & Source \\
\hline Tourist arrivals & TA & Annual tourist arrivals per capita from origin country & Ministry of Tourism Malaysia (2008) \\
\hline Income & GDP & The real GDP per capita in the origin country in US\$ & International Financial Statistics (IFS, 2008) \\
\hline Tourism price & $\mathrm{TP}$ & $\begin{array}{l}\text { The relative CPI Malaysia divided by CPI in origin } \\
\text { country adjusted by exchange rate }\end{array}$ & International Financial Statistics (IFS, 2008) \\
\hline Substitute price & TPS & $\begin{array}{l}\text { The weighing consumer price index of each of the five } \\
\text { substitute destinations }\end{array}$ & World Tourism Organization (WTO, 2008) \\
\hline Travel cost & $\mathrm{TC}$ & The price of crude oil & Energy Information Administration (EIA, 2008) \\
\hline Trade value & TV & The total value of import and export of goods and services & Direction Trade Statistics (DTS, 2008) \\
\hline
\end{tabular}


Am. J. Applied Sci., 6 (11): 1924-1931, 2009

The second step is to examine the null hypothesis (of no cointegration) against the alternative hypothesis (there is cointegration) between all variables by using Wald- coefficient or F-test with the respective critical values. In the next step, we estimate the short run and long run elasticities. We have followed the Unrestricted Error Correction Model (UECM) Case III, which are unrestricted intercepts and no trends based on the assumption made by ${ }^{[28]}$. Equation 1 can be expressed in the UECM version of the ARDL model as follows:

$$
\begin{aligned}
\Delta \ln \mathrm{TA}_{\mathrm{t}}= & \beta_{0}+\sum_{\mathrm{p}=1}^{\mathrm{n}} \mathrm{b}_{\mathrm{p}} \Delta \ln \mathrm{TA}_{\mathrm{t}-\mathrm{p}} \\
& +\sum_{\mathrm{p}=0}^{\mathrm{n}} \mathrm{c}_{\mathrm{p}} \Delta \ln \mathrm{Y}_{\mathrm{t}-\mathrm{p}}+\sum_{\mathrm{p}=0}^{\mathrm{n}} \mathrm{d}_{\mathrm{p}} \Delta \ln \mathrm{TP}_{\mathrm{t}-\mathrm{p}} \\
& +\sum_{\mathrm{p}=0}^{\mathrm{n}} \mathrm{e}_{\mathrm{p}} \Delta \ln \mathrm{TC}_{\mathrm{t}-\mathrm{p}}+\sum_{\mathrm{p}=0}^{\mathrm{n}} \mathrm{f}_{\mathrm{p}} \Delta \ln \mathrm{TPS}_{\mathrm{j}, \mathrm{t}-\mathrm{p}} \\
& +\sum_{\mathrm{p}=0}^{\mathrm{n}} \mathrm{j}_{\mathrm{p}} \Delta \ln \mathrm{TV}_{\mathrm{t}-\mathrm{p}}+\lambda_{1} \ln \mathrm{TA}_{\mathrm{t}-1}+\lambda_{2} \operatorname{InY}_{\mathrm{t}-1} \\
& +\lambda_{3} \operatorname{InTP}_{\mathrm{t}-1}+\lambda_{4} \operatorname{InTPS}_{\mathrm{t}-1}+\lambda_{5} \operatorname{InTV}_{\mathrm{j}, \mathrm{t}-1} \\
& +\lambda_{6} \operatorname{InTV}_{\mathrm{t}-1}+\lambda_{7} \mathrm{D} 03+\varepsilon_{1 \mathrm{t}}
\end{aligned}
$$

The second step is to examine the existence of long run cointegration relationship among all variables. The F-test is used for testing the existence of long run relationships. The null hypothesis for no cointegration between the variables in Eq. 5 is:

$$
\begin{aligned}
& \left(\mathrm{H}_{0}: \lambda_{1}=\lambda_{2}=\lambda_{3}=\lambda_{4}=\lambda_{5}=\lambda_{6}=0\right) \\
& \left(\mathrm{H}_{\mathrm{a}}: \lambda_{1} \neq \lambda_{2} \neq \lambda_{3} \neq \lambda_{4} \neq \lambda_{5} \neq \lambda_{6} \neq 0\right)
\end{aligned}
$$

If the computed F-statistics is higher than the upper bound Critical Value (CV), the null hypothesis of no cointegration is rejected, therefore there is a long run relationship between tourist arrivals, income, tourism price, tourism price substitute and travel cost. If the computed F-statistics is smaller than lower bound Critical Value $(\mathrm{CV})$, then the null hypothesis of no cointegration cannot be rejected. The third step is to estimate the elasticities of the short run and long run relationship. The long run elasticities are calculated from the estimated respective coefficients of the one lagged level explanatory (independent) variables divided by the coefficient of the one lagged level dependent variable (multiplied with a negative sign).

\section{RESULTS}

The analysis begins by investigating the unit root test of variables using the Augmented Dickey-Fuller ${ }^{[29]}$. The results indicate that all variables are integrated of order zero $\mathrm{I}(0)$ or order one $\mathrm{I}(1)$. The calculated Fstatistics in the Wald test as reported in Table 3 is greater than the upper bound critical value at $1 \%$ level for all countries except Singapore and Australia at 5\% level. Thus, the null hypothesis of no cointegration is rejected. There is really a cointegration relationship between tourist arrivals, income, tourism price, tourism substitute price, travel cost and trade value. The selection of the order of the ARDL model for the computation of the long run coefficients is based on Akaike's information criteria up to two lags and results are presented in Table 4.

Income: Income is an important variable in all countries except for Brunei, Australia and UK. The results indicate that the coefficient of income have the correct sign and elastic except for Singapore, Thailand and Philippines. For example, a $1 \%$ increase in income in Japan would increase by $6 \%$ tourist arrivals from India.

Tourism price: Tourism price is another important factor which affected tourism demand. The estimated coefficient of tourism price has the correct sign (negative) and significant in all countries except for Singapore and India.

\begin{tabular}{|c|c|c|c|c|c|}
\hline \multirow[b]{2}{*}{ Country } & \multirow[b]{2}{*}{ F-computed } & \multicolumn{2}{|c|}{$1(\%)$} & \multicolumn{2}{|c|}{$5(\%)$} \\
\hline & & $\mathrm{I}(0)$ & $\mathrm{I}(1)$ & $\mathrm{I}(0)$ & $\mathrm{I}(1)$ \\
\hline Singapore & 5.61 & 4.53 & 6.37 & 3.12 & 4.6 \\
\hline Indonesia & 7.05 & & & & \\
\hline Thailand & 6.66 & & & & \\
\hline Brunei & 6.65 & & & & \\
\hline China & 10.00 & & & & \\
\hline India & 6.61 & & & & \\
\hline Japan & 9.31 & & & & \\
\hline Philippines & 8.95 & & & & \\
\hline Australia & 4.99 & & & & \\
\hline UK & 7.99 & & & & \\
\hline
\end{tabular}
The negative sign of tourism price indicated that increase in price of goods and services which purchased by tourists in Malaysia consequence to decrease their arrivals to Malaysia. For example, the estimated tourism price elasticity suggests that $1 \%$ increase in price of goods and

\begin{tabular}{|c|c|c|c|c|c|}
\hline Country & LY & LTP & LTPS & LTC & LTV \\
\hline Singapore & $-3.25 * * *$ & -2.58 & $-3.86^{* * *}$ & 0.57 & $1.1 * *$ \\
\hline Indonesia & $2.30 * *$ & $-4.56^{*}$ & $5.56^{* *}$ & $0.17 * *$ & -4.67 \\
\hline Thailand & $-0.640 * *$ & $0.14^{*}$ & $-5.33 * * *$ & 0.300 & $-1.11 * *$ \\
\hline Brunei & 0.960 & $-3.45 * * *$ & $0.25 * *$ & -1.040 & $0.43^{* *}$ \\
\hline China & 2.530 *** & $-8.09 * * *$ & 2.26 & $-0.050 * * *$ & $1.02 * * *$ \\
\hline India & $6.380^{* * *}$ & -7.03 & $-0.73 * *$ & $0.410 * *$ & $1.23 * *$ \\
\hline Japan & $3.860 * * *$ & $-5.45 * *$ & $2.94 * *$ & $-0.150^{*}$ & $-2.12 * *$ \\
\hline Philippines & $-1.120 * *$ & $-0.91 *$ & $-4.93 * * *$ & 1.250 & 0.03 \\
\hline Australia & 0.450 & $-1.18 * * *$ & $1.37 * *$ & $0.020 * *$ & $0.81 * * *$ \\
\hline UK & 4.100 & $1.03 * *$ & $-3.96 * * *$ & $-0.160 * * *$ & $2.09 * * *$ \\
\hline
\end{tabular}
services in Malaysia lead to in $8 \%$ decrease in tourist arrivals to Malaysia from China.

Critical values for the partial F-statistics were obtained from Narayan ${ }^{[10]}$, table of critical value of bound test case III: Unrestricted intercept and no trend)

Table 4: Estimation of long run elasticities of the model

Note: Significance levels denoted as follows $* * * *:(1 \%)$, **: $(5 \%)$ and *: $(10 \%)$ 
Am. J. Applied Sci., 6 (11): 1924-1931, 2009

Table 5: Results of short run granger causality

\begin{tabular}{|c|c|c|c|c|c|c|c|c|c|c|}
\hline Variable & Singapore & Indonesia & Thailand & Brunei & China & India & Japan & Philippines & Australia & UK \\
\hline$\Delta \mathrm{LTA}_{(-1)}$ & - & $0.57 * * *$ & $0.14 * *$ & $0.63 * *$ & $0.27 * *$ & - & $0.23^{* *}$ & $0.30^{* * *}$ & $0.81^{* * * *}$ & - \\
\hline$\Delta \mathrm{LTA}_{(-2)}$ & $0.21 * *$ & $-0.37 * * *$ & - & $0.64 * * *$ & - & 0.01 & - & - & $0.48 * *$ & 0.19 \\
\hline$\Delta \mathrm{LY}$ & $1.31 *$ & $-5.59 * * *$ & - & -0.39 & $-1.51^{* *}$ & $3.87 * *$ & $9.59^{*}$ & $0.27 * * *$ & - & - \\
\hline$\Delta \mathrm{LY} Y_{(-1)}$ & - & - & - & - & - & - & - & $1.32 * *$ & $12.21 * *$ & $2.69 * * *$ \\
\hline$\Delta \mathrm{LY}_{(-2)}$ & - & - & 0.45 & - & 0.18 & $1.27 *$ & - & - & - & - \\
\hline$\triangle \mathrm{LTP}$ & $-7.64 *$ & - & - & -3.31 & - & - & - & - & $-2.55^{* * *}$ & - \\
\hline$\Delta \operatorname{LTP}_{(-1)}$ & - & - & $4.27 *$ & - & - & - & $-6.03 * *$ & $-2.21 * * *$ & - & $2.04 * * *$ \\
\hline$\Delta \operatorname{LTP}_{(-2)}$ & - & $1.29 * * *$ & - & - & $-1.82 * *$ & - & - & $2.45^{* * *}$ & - & - \\
\hline$\Delta$ LTPS & $-4.54 * * * *$ & - & - & - & - & - & $7.07^{* * * *}$ & - & - & - \\
\hline$\Delta \operatorname{LTPS}_{(-1)}$ & $5.84 *$ & $6.10^{* *}$ & - & $-4.18 * *$ & $-0.78^{* * *}$ & - & - & -2.41 & $2.61^{*}$ & \\
\hline$\Delta \operatorname{LTPS}_{(-2)}$ & - & - & $0.94 * *$ & & - & $-3.87 * * *$ & $6.85^{* * * *}$ & - & - & \\
\hline$\Delta \mathrm{LTC}$ & - & - & 0.35 & $-2.73 * * *$ & $-1.10^{* * *}$ & - & - & - & - & -0.41 \\
\hline$\Delta \mathrm{LTC}_{(-1)}$ & $-0.55^{* * *}$ & $-0.38^{*}$ & - & - & - & - & - & - & $0.51^{*}$ & - \\
\hline$\Delta \mathrm{LTC}_{(-2)}$ & - & - & - & - & - & -0.41 & - & $-0.44 *$ & - & - \\
\hline$\Delta \mathrm{LTV}$ & - & - & - & $0.89 * *$ & - & - & $0.88^{*}$ & 0.09 & -0.44 & -0.75 \\
\hline$\Delta \mathrm{LTV}_{(-1)}$ & - & - & $1.44 * *$ & - & - & - & - & - & - & - \\
\hline$\Delta \operatorname{LTV}_{(-2)}$ & $1.27 * * *$ & $-2.09^{* * * *}$ & - & - & $0.52 * *$ & $0.95^{* *}$ & - & - & - & - \\
\hline & $-0.48 * * *$ & $-1.04 * * *$ & -0.16 & $-1.14 * *$ & $-1.89^{* * * *}$ & $-3.68^{* * * *}$ & $-1.41^{* * * *}$ & $-0.84 * * *$ & $-0.72^{* * * *}$ & $-0.51^{* * * *}$ \\
\hline \multicolumn{11}{|c|}{ Diagnostic tests } \\
\hline Test A & $3.02[0.22]$ & $0.95[0.62]$ & $3.86[0.14]$ & $0.09[0.99]$ & $0.25[0.88]$ & $1.34[0.51]$ & $1.58[0.45]$ & $1.51[0.47]$ & $1.37[0.50]$ & $0.50[0.77]$ \\
\hline Test B & $0.33[0.56]$ & $0.25[0.62]$ & $1.85[0.18]$ & $0.45[0.50]$ & $0.13[0.87]$ & $0.78[0.38]$ & $5.57[0.03]$ & $0.33[0.56]$ & $2.34[0.14]$ & $1.21[0.18]$ \\
\hline Test C & $0.49[0.48]$ & $0.72[0.49]$ & $0.49[0.48]$ & $0.05[0.81]$ & $1.32[0.25]$ & $0.50[0.48]$ & $0.29[0.59]$ & $0.64[0.42]$ & $0.88[0.35]$ & $1.58[0.21]$ \\
\hline Test D & $0.02[0.87]$ & $0.42[0.52]$ & $2.31[0.14]$ & $3.54[0.07]$ & $0.70[0.41]$ & $3.37[0.08]$ & $0.60[0.44]$ & $0.09[0.76]$ & $0.18[0.67]$ & $1.14[0.30]$ \\
\hline
\end{tabular}

Notes: $\Delta$ : Denotes the first difference of variables, [ ]: Denote the probability, Significance levels denoted as follows ****: (1\%), **: (5\%) and *: $(10 \%), A, B, C$ and are the tests for normality, residual autocorrelation, heteroskedasticity and functional form respectively

Tourism price substitute: In this study the selected five competing destinations acquired a large market share from the nine competitor destinations. Specifically, China, Indonesia, Singapore, Thailand and Hong Kong picked up on average $80 \%$ of the tourist market. The sign of substitute tourism prices at the alternative destinations can be positive or negative. Positive sign implies that the alternative destination is a substitute destination for Malaysia or otherwise is a complementary destination. The results indicate that tourism price substitute is negative sign (complementary destination) in all of countries except for Singapore, Thailand and UK. Hence, for example, a $1 \%$ increase in price of goods and services in China, Indonesia, Singapore, Thailand and Hong Kong would lead to an increase of $1.03 \%$ of UK tourists.

Travel cost: Travel of cost is significant in the Indonesia, China, Japan and UK. For example, 1\% increase in travel cost will lead to decrease in tourist arrivals from China by $0.05 \%$.

Trade value: The coefficient of trade value has significant and positive sign in all countries except for Indonesia, Japan and Philippines: The results indicated that a $1 \%$ increase in trade value between Malaysia and UK would lead to $2.09 \%$ increase in tourist arrivals from UK.

Table 5 shows that the most of short run elasticites estimation of variables are significant. The results of short run Granger causality indicate that the word of mouth and the outbreak of SARS (D03) have an expected sign and significance in all countries except for Thailand and UK. Several diagnostic tests were carried out to ensure the model is an appropriate model, such as the test for serial correlation (LM test), heteroscedasticity (ARCH test), normality (JB (N)) and functional form. The statistics reported shows that there are no problems associated with serial correlation, normality or heteroscedasticity ${ }^{[31]}$.

\section{CONCLUSION}

The objective of this study is to analyses the long run and short run relationship between tourist arrivals and income, tourism price, tourism price substitute, travel cost and trade value. In addition dummy variable of the outbreak of SARS in 2003 are also included as short run analysis. A single cointegration technique, ARDL in version ECM, was applied to estimate tourism demand from top ten countries to Malaysia. The results indicate that there is a cointegration between the variables. Most of the variables are significant in the long run as well as for the short run granger causality. Knowledge of the variables that influence the demand for international tourism is valuable to policy makers in planning growth strategies for the tourism industry in Malaysia. The tourists from these countries seem to be highly sensitive to the price variable. Hence, policy makers and suppliers must closely monitor all tourism service providers such as hotels, restaurants, tourist operators and transportation companies such as airport taxis and tourist buses to ensure that they do not charge 'unreasonable' prices for their services. As the demand is price elastic, a small percentage reduction in price could attract a large 
percentage of tourist arrivals and the pay-off could be significant.

\section{REFERENCES}

1. Ganesan, V., 2005. Tourism Malaysia expects higher budget allocation. Business Times, 7 .

2. Government Malaysia, Ninth Malaysia Plan 20062010. http://www.epu.gov.my/ninth

3. Ministry of Tourism Malaysia, Tourism Statistics Update1998-2007.

http://www.tourismmalaysia.gov.my/corporate/rese arch.asp?page=facts_figures

4. World Tourism Organization, 2007. Tourism Highlights 2007. http://www.world-tourism.org.

5. Crouch, G.I., 1995. A meta-analysis of tourism demand. Ann. Tourism Res., 22: 103-118. http://www.ingentaconnect.com/content/els/01607 383/1995/00000022/00000001/art00054

6. Witt, S.F. and C.A. Witt, 1995. Forecasting tourism demand: A review of empirical research. Int. J. Forecast., 11: 447-475. http://ideas.repec.org/a/eee/intfor/v11y1995i3p447475.html

7. Lim, C., 1999. A meta-analytic review of international tourism demand. J. Travel Res., 37: 273-284. DOI: 10.1177/004728759903700309

8. Kulendran, N. and S. Divisekera, 2007. Measuring the economic impact of Australian tourism marketing expenditure. Tourism Econ., 13: 261-274. http://www.ingentaconnect.com/content/ip/tec/200 7/00000013/00000002/art00006

9. Algieri, B., 2006. An econometric estimation of the demand for tourism: The case of Russia. Tourism Econ., $\quad 12$ : 5-20. http://www.ingentaconnect.com/content/ip/tec/200 6/00000012/00000001/art00001

10. Narayan, P.K., 2004. Fiji's tourism demand: The ARDL approach to cointegration. Tourism Econ., 10: 193-206.

http://www.ingentaconnect.com/content/ip/tec/200 4/00000010/00000002/art00005

11. Song, H., S.F. Witt and G. Li, 2003. Modeling and forecasting the demand for Thai tourism. Tourism Econ., 9: 363-387. http://www.ingentaconnect.com/content/ip/tec/200 3/00000009/00000004/art00002

12. Ouerfell, C., 2008. Co-integration analysis of quarterly European tourism demand in Tunisia. Tourism Manage., 29: 127-137. DOI: 10.1016/j.tourman.2007.03.022
13. Dritsakis, N., 2004. Cointegration analysis of German and British tourism demand for Greece. Tourism Mange., 25: 111-119. DOI: 10.1016/S0261-5177(03)00061-X

14. Hbibi, F., K. Rahim and L. Chin, 2008. Cointegration analysis of Australia tourism demand for Malaysia. Proceeding of the FEP Conference, Dec. 2008, Melaka, Malaysia.

15. Salleh, N. H.M., R. Othman and S. Ramachandran, 2007. Malaysia's tourism demand from selected countries: The ARDL approach to cointegration. Int. J. Econ. Manage., 1: 345-363. http://psasir.upm.edu.my/672/

16. Hanly, P. and G. Wade, 2007. Modeling tourism demand-an econometric analysis of North American tourist expenditure in Ireland, 19852004. Tourism Econ., 13: 319-327. http://www.ingentaconnect.com/content/ip/tec/200 7/00000013/00000002/art00010

17. Merver, A. and E.J. Payne, 2007. Analysis of foreign tourism demand for Croatian destination: Long-run elasticity estimates. Tourism Econ., 3: 407-420.

http://www.ingentaconnect.com/content/ip/tec/200 7/00000013/00000003/art00005

18. Athanasopoulos, G. and J.R. Hyndman, 2008. Modeling and forecasting Australian domestic tourism. Tourism Manage., 29: 19-31. DOI: 10.1016/j.tourman.2007.04.009

19. Song, H., F. Kevin and K. Chon, 2003. Modeling and forecasting the demand for Hong Kong tourism. Hospit. Manage., 22: 435-451. DOI: 10.1016/S0278-4319(03)00047-1

20. Carey, K., 1991. Estimation of Caribbean tourism demand: Issues in measurement and methodology. Atlant. Econ. J., 19: 32-40. DOI: 10.1007/BF02299101

21. Kulendran, N, and S. F. Witt, 2003. Forecasting the demand for international business tourism. J. Travel Res., 41: 265-271. http://jtr.sagepub.com/cgi/content/abstract/41/3/265

22. Dwyer, L., P. Forsyth and P. Rao, 2000. The price competitiveness of travel and tourism: A comparison of 19 destinations. Tourism Manage., 21: 9-22. DOI: 10.1016/S0261-5177(99)00081-3

23. Turner, L.W. and S.F. Witt, 2001. Factors influencing demand for international tourism: Tourism demand analysis using structural equation modeling, revisited. Tourism Econ., 7: 21-38. http://www.ingentaconnect.com/content/ip/tec/200 1/00000007/00000001/art00002?crawler=true 
24. Turner, L.W., Y. Reisinger and S.F. Witt, 1998. Tourism demand analysis using structural equation modeling. Tourism Econ., 4: 301-324. http://direct.bl.uk/bld/PlaceOrder.do?UIN=057130 $556 \&$ ETOC $=$ RN \& from $=$ searchengine

25. Gujarati, N.D., 2003. Essential of Econometrics. 4th Edn., McGraw-Hill, ISBN: 0-07-233542-4, pp: 817.

26. Pesaran, M. and Y. Shin, 1995. Long run structural modeling. DAE Working Paper, Department of Applied Economics, University of Cambridge. http://ideas.repec.org/p/edn/esedps/44.html

27. Pesaran, M.H., Y. Shin and R.J. Smith, 1996. Testing for the existence of a long-run relationship. DAE Working Paper, (No. 9622), Department of Applied Economics, University of Cambridge. http://ideas.repec.org/p/cam/camdae/9622.html

28. Pesaran, M.H., Y. Shin and R.J. Smith, 2001. Bounds testing approaches to the analysis of longrun relationship. J. Applied Econ., 16: 289-326. http://www.jstor.org/pss/2678547
29. Dickey, D.A. and W.A. Fuller, 1979. Distribution of the estimators for autoregressive time series with a unit root. J. Am. Stat. Assoc., 74: 427-431. http://www.jstor.org/pss/2286348

30. International Monetary Found, 2008. International Financial Statistics (IFS). (CDROM-2008). http://www.gsb.stanford.edu/jacksonlibrary/articles /databases/dbguides/ifs.pdf

31. International Monetary Found, 2008. Direction of trade statistics CD ROM subscription. http://www.imf.org/external/pubs/cat/longres.cfm? sk=20720.0

32. Energy Information Administration (EIA), 2008. http://www.eia.doe.gov 